\title{
KAJIAN PENGGUNAAN BEBERAPA BAHAN ALAMI SEBAGAI SUMBER ZPT DAN METODE SAYATAN TERHADAP SAMBUNG PUCUK DURIAN (Durio zibethinus Murr.)
}

\author{
Nurrisah Patmasari ${ }^{1}$, Amarullah $^{2}$ \\ ${ }^{1,2}$ Program Studi Agroteknologi, Fakultas Pertanian, Universitas Borneo Tarakan \\ Email: nurrisah03@gmail.com
}

\begin{abstract}
Durian fruit production in Indonesia has increased every year, in 2014 durian production reached 859,118 tons. The provision of high quality and high quality seeds is a factor that determines the success of durian cultivation. Vegetative propagation is an alternative to get high- quality seeds that do not deviate from the nature of the parent and harvest time faster. Growth regulators are non-nutritional organic compounds which at low concentrations can encourage, inhibit or qualitatively change plant growth and development. So to get superior quality durian seedlings it is necessary to do a combination of incision type treatment and natural ZPT type. Time and place at the Screen House of the Faculty of Agriculture, University of Borneo Tarakan in February April 2019, Factor I was the application of natural PGR with 3 treatments as follows H1: Coconut water, H2: Shallot Extract, H3: Bean sprout extract. Factor II is the type of incision at the top of the shoot with 3 treatments as follows: S1: Slit joint type, S2: Type of C-25 Connect, S3: Insert Type of Insert. The parameters of success continued survival (\%), number of leaves (strands), Increase in entres length $(\mathrm{cm})$, Diameter of upper stem $(\mathrm{cm})$, Diameter of lower stem $(\mathrm{cm})$. calculation data using variance and DMRT follow-up test level of 5\%. The results of this study on the parameters of success of survival and increase in entres length there is the effect of a combination of treatment of natural growth regulators and incision types. On the success parameters of live grafting which shows the highest value, namely H2S1 (ZPT onion extract and gaps join). Whereas the parameter entres length increase showed the highest value, namely H1S1 (ZPT coconut water andgaps).
\end{abstract}

Keywords: Durian, combination, type of incision, natural ZPT

\begin{abstract}
ABSTRAK
Produksi buah durian di Indonesia setiap tahun mengalami peningkatan, tahun 2014 produksi durian mencapai 859.118 ton. Penyediaan bibit varietas unggul dan berkualitas merupakan faktor yang menentukan keberhasilan budidaya durian. Perbanyakan tanaman secara vegetatif merupakan alternatif untuk mendapatkan bibit berkualitas tinggi yaitu tidak menyimpang dari sifat induknya dan masa panen lebih cepat. Zat pengatur tumbuh adalah senyawa organik bukan nutrisi yang pada konsentrasi rendah dapat mendorong, menghambat atau secara kualitatif merubah pertumbuhan dan perkembangan tanaman. Sehingga untuk mendapatkan bibit durian kualitas unggul perlu dilakukan kombinasi perlakuan tipe sayatan dan jenis ZPT alami. Waktu dan tempat di Screen House Fakultas Pertanian Universitas Borneo Tarakan pada bulan Februari - April 2019, Faktor I adalah pengaplikasian ZPT alami dengan 3 perlakuan sebagai berikut H1 : Air kelapa, H2 : Ekstrak Bawang merah, H3 : Ekstrak tauge. Faktor II adalah tipe sayatan pada sambung pucuk dengan 3 perlakuan sebagai berikut : S1 : Tipe sambung celah, S2 : Tipe Sambung Canggap, S3 : Tipe Sambung Sisip. Parameter Keberhasilan sambung hidup (\%), Jumlah daun (helai), Pertambahan panjang entres $(\mathrm{cm})$, Diameter batang atas $(\mathrm{cm})$, Diameter batang bawah $(\mathrm{cm})$. data perhitungan menggunakan sidik ragam dan uji lanjut DMRT taraf 5\%. Hasil penelitian ini pada parameter keberhasilan sambung hidup dan pertambahan panjang entres terdapat pengaruh kombinasi perlakuan zat pengatur tumbuh alami dan tipe sayatan. Pada parameter keberhasilan sambung hidup yang menunjukkan nilai tertinggi yaitu H2S1 (ZPT ekstrak bawang merah dan sambung celah). Sedangkan pada parameter pertambahan panjang entres menunjukkan nilai tertinggi yaitu H1S1 (ZPT air kelapa dan sambungcelah).
\end{abstract}

Kata kunci : Durian, Kombinasi, Tipe sayatan, ZPT alam

\section{PENDAHULUAN}

Durian (Durio zibethinus Murr) merupakan salah satu buah yang mengandung zat gizi dan dijuluki sebagai "the king of the fruit". Buah durian (Durio zibethinus Murr) merupakan salah satu buah tropika yang dipercaya berasal dari Asia Tenggara. Pada umumnya buah durian dikonsumsi dalam bentuk segar, namun saat ini 
sudah banyak juga yang diolah menjadi produk lain, seperti permen, keripik, dodol, biskuit, bahan makanan lain berupa tepung untuk campuran es krim dan roti (Somsri,2008).

Produksi buah durian di Indonesia dari tahun ke tahun mengalami peningkatan, pada tahun 2014 produksi buah durian mencapai 859.118 ton. Pada tahun 2015 produksi buah durian mencapai 995.729 ton. Namun pada tahun 2016 produksi buah durian menurun drastis menjadi 735.419 ton (Badan Pusat Statistik 2016). Untuk daerah Kalimantan Utara produksi buah durian pada tahun 2015 sebesar 3.333 ton dan pada tahun 2016 sebesar 4.364 ton (Badan Pusat Statistik 2016).

Rendahnya produksi buah durian di Kalimantan Utara salah satunya disebabkan sebagian besar tanaman durian tidak ditanam secara massal, hanya dijadikan sebagai tanaman pekarangan dan tidak dipellihara dengan baik. Penyediaan bibit varietas unggul dan berkualitas merupakan salah satu faktor yang menentukan keberhasilan budidaya durian Selain itu, tanaman durian yang ada saat ini umumnya berasal dari benih yang kualitasnya sangat beragam serta bibit berasal dari biji yang menyebabkan produksi dengan variabilitas tinggi dan produktivitas rendah, sehingga belum mampu mencukupi permintaan konsumen baik dalam negeri maupun luar negeri (Yuniastuti, 2009).

Perbanyakan secara generatif pada umumnya memerlukan waktu yang cukup lama, namun kelebihan perbanyakan dari benih adalah secara umum batang pohon hasil benih lebih kokoh, sehat dan berumur panjang (Nazaruddin, Muchlisah 1994). Perbanyakan tanaman secara vegetatif merupakan alternatif untuk mendapatkan bibit berkualitas tinggi yaitu tidak menyimpang dari sifat induknya dan masa panen lebih cepat. Perbanyakan secara vegetatif dapat dilakukan dengan pencangkokan, okulasi maupun grafting (sambung pucuk). Tipe sambungan yang dapat dilakukan pun bermacam-macam, yaitu tipe sambung celah, tipe sambung canggap dan tipe sambung sisip (Sumarsono et al.2002).

Zat pengatur tumbuh adalah senyawa organik bukan nutrisi yang pada konsentrasi rendah dapat mendorong, menghambat atau secara kualitatif merubah pertumbuhan dan perkembangan tanaman. Zat pengatur tumbuh yang diaplikasikan ke tanaman ada yang alami dan sintetis. Zat pengatur tumbuh alami didapat dari jaringan muda tanam diantaranya air kelapa muda, ekstrak kecambah kacang hijau (taoge) dan extrak bawa merah. Air kelapa muda dapat dimanfaatkan untuk meningkatkan pertumbuhan tanaman (Arif et al. 2016)

Hasil penelitian Simtalia (2013), menunjukkan bahwa pemberian air kelapa sebanyak $750 \mathrm{cc} / 1$ air dapat mempercepat pertumbuhan stum mata tidur bibit karet. Morel (1974) menyatakan air kelapa muda mengandung asam amino, asam nukleat, purin, karbohidrat, sedikit lemak, gula, alkohol, vitamin $\mathrm{C}$ dan $\mathrm{B}$, mineral dan hormon seperti sitokinin $5,8 \mathrm{mg} / \mathrm{l}$, auksin $0,07 \mathrm{mg} / \mathrm{l}$ dan sedikit giberelin yang dapat menstimulasi pertumbuhan.

Auksin juga terkandung pada kecambah kacang hijau (taoge). Hasil penelitian Amilah, Astuti (2006), menunjukkan bahwa penggunaan ekstrak taoge sebanyak $150 \mathrm{~g} / \mathrm{l}$ memberikan hasil yang tinggi pada tanaman anggrek bulan.Menurut Muswita (2011) pemberian bawang merah terhadap stek gaharu berpengaruh terhadap persentase hidup stek dengan konsentrasi $1 \%(10 \mathrm{cc} / \mathrm{liter}$ air $)$ dan jumlah akar stek gaharu dengan konsentrasi 0,5 $\%$ ( 5 cc/liter air).

Berdasarkan uraian di atas, maka dilakukan penelitian untuk mengetahui penggunaan beberapa bahan alami sebagai sumber zpt alami dan metode sayatan terhadap keberhasilan sambung pucuk durian (Durio zibethinua Murr)

\section{METODE}

Tempat dan Waktu Penelitian

Penelitian ini akan dilaksanakan di Screen House Fakultas Pertanian Universitas Borneo Tarakan pada bulan Februari hingga April 2019. Rancangan Penelitian

Penelitian ini menggunakan rancangan acak Kelompok (RAK) dengan 2 faktor masingmasing faktor 3 perlakuan dengan 6 ulangan, maka diperoleh 108 unit percobaan dari 2 faktor penelitian. Adapun perlakuan dalam penelitian ini :

Faktor I adalah pengaplikasian ZPT alami dengan 3 perlakuan sebagai berikut : H1 : Air kelapa $\mathrm{H} 2$ : Ekstrak Bawang merah H3 : Ekstrak tauge

Faktor II adalah tipe sayatan pada sambung pucuk dengan 3 perlakuan sebagai berikut :

S1 : Tipe sambung celah S2 : Tipe Sambung Canggap S3 : Tipe SambungSisip

Parameter Pengamatan

1.Keberhasilan Sambung Hidup(\%)

2.Jumlah Daun(helai)

3.Pertambahan Panjang Entres $(\mathrm{cm})$

4.Diameter Batang Atas $(\mathrm{cm})$ 
5.Diameter Batang Atas $(\mathrm{cm})$

\section{HASIL DAN PEMBAHASAN}

Tabel. 1 Keberhasilan Sambung Hidup (\%)

\begin{tabular}{|c|c|c|c|c|}
\hline \multicolumn{2}{|c|}{ Pengaruh Tunggal } & \multicolumn{2}{|c|}{ Pengaruh Tunggal Sayatan } & \multirow{2}{*}{$\begin{array}{l}\text { Pengaruh Umum } \\
\text { ZPT }\end{array}$} \\
\hline ZPT & S1 & $\mathrm{S} 2$ & S3 & \\
\hline$\overline{\mathrm{H} 1}$ & $66,67 \mathrm{a}$ & $8,33 \mathrm{~b}$ & $25,00 \mathrm{~b}$ & 33,89 a \\
\hline $\mathrm{H} 2$ & $66,67 \mathrm{a}$ & $25,00 \mathrm{~b}$ & $25,00 \mathrm{~b}$ & 38,89 a \\
\hline $\mathrm{H} 3$ & $25,00 \mathrm{~b}$ & $8,33 \mathrm{~b}$ & $41,67 \mathrm{ab}$ & $25,78 \mathrm{a}$ \\
\hline
\end{tabular}

Pengaruh Umum Sayatan 52,78

$13,89 \mathrm{~b} \quad 30,56 \mathrm{ab}$

Ket: $\quad$ H1= ZPT air kelapa, H2= ZPT ekstrak bawang merah, H3= ZPT ekstrak tauge, $\mathrm{S} 1=$ tipe sambung pucuk celah $\mathrm{S} 2=$ tipe sambung pucuk canggap S3= tipe sambung pucuksisip

Berdasarkan Tabel 1, kombinasi perlakuan zat pengatur tumbuh dan tipe sayatan yang menunjukkan nilai tertinggi pada perlakuan yaitu H1S1 (ZPT air kelapa dan sambung celah) dan H2S1 (ZPT ekstrak bawang merah dan sambung celah) dengan nilai 66, 67.

Tabel. 2 Jumlah Daun (helai)

\begin{tabular}{lllll}
\hline Pengaruh Tunggal & \multicolumn{2}{c}{ Pengaruh TunggalSayatan } & Pengaruh Umum \\
ZPT & S1 & S2 & S3 & ZPT \\
\hline H1 & $3,42 \mathrm{a}$ & $1,17 \mathrm{~b}$ & $1,83 \mathrm{ab}$ & $2,14 \mathrm{a}$ \\
$\mathrm{H} 2$ & $2,58 \mathrm{ab}$ & $1,50 \mathrm{ab}$ & $0,67 \mathrm{~b}$ & $1,58 \mathrm{a}$ \\
$\mathrm{H} 3$ & $1,42 \mathrm{ab}$ & $0,67 \mathrm{~b}$ & $2,67 \mathrm{ab}$ & $1,58 \mathrm{a}$ \\
\hline Penaruh Umum Sayatan & $2,47 \mathrm{a}$ & $1,11 \mathrm{a}$ & $1,72 \mathrm{a}$ &
\end{tabular}

Ket:H1 = ZPT air kelapa, H2= ZPT ekstrak bawang merah, H3=ZPT ekstrak tauge, S1 = tipe sambung pucuk celah $\mathrm{S} 2=$ tipe sambung pucuk canggap $\mathrm{S} 3=$ tipe sambung pucuk sisip.

Berdasarkan Tabel 2, menunjukkan perlakuan kombinasi jenis zat pengatur tumbuh dan tipe sayatan yang terdapat nilai tertinggi pada perlakuan yaitu H1S1 (ZPT air kelapa dan sambung celah) dengan nilai 3,42 cm dan H2S1 (ZPT ekstrak bawang merah dan sambung celah) dengan nilai $2,58 \mathrm{~cm}$

Tabel. 3 Pertambahan Panjang Entres (cm)

\begin{tabular}{|c|c|c|c|c|}
\hline Pengaruh Tunggal & \multicolumn{3}{|c|}{ Pengaruh TunggalSayatan } & Pengaruh Umum \\
\hline ZPT & S1 & S2 & 3 & $\mathrm{ZPT}$ \\
\hline H1 & $5,68 \mathrm{a}$ & $0,98 \mathrm{c}$ & $2,31 \mathrm{bc}$ & $2,97 \mathrm{a}$ \\
\hline $\mathrm{H} 2$ & $4,02 \mathrm{abc}$ & $2,31 \mathrm{bc}$ & $1,70 \mathrm{bc}$ & $2,68 \mathrm{a}$ \\
\hline $\mathrm{H} 3$ & $2,08 \mathrm{bc}$ & $0,97 \mathrm{c}$ & $4,40 \mathrm{ab}$ & $2,48 \mathrm{a}$ \\
\hline Pengaruh Umum & $3,93 \mathrm{a}$ & $1,42 \mathrm{a}$ & $2,78 \mathrm{a}$ & \\
\hline
\end{tabular}

Sayatan

Ket: $\quad$ H1= ZPT air kelapa, H2= ZPT ekstrak bawang merah, H3= ZPT ekstrak tauge, S1= tipe sambung pucuk celah $\mathrm{S} 2=$ tipe sambung pucuk canggap $\mathrm{S} 3=$ tipe sambung pucuksisip

Berdasarkan Tabel 3, kombinasi perlakuan jenis zat pengatur tumbuh dan tipe sayatan yang menunjukkan nilai tertinggi pada semua perlakuan yaitu H1S1 (ZPT air kelapa dan sambung celah) dengan nilai tertinggi yaitu $5,68 \mathrm{~cm}$.

Tabel. 4 Diameter Batang Atas (cm)

\begin{tabular}{lllll}
\hline Pengaruh Tunggal & \multicolumn{3}{c}{ Pengaruh Tunggal Sayatan } & Pengaruh Umum \\
\cline { 2 - 5 } ZPT & S1 & S2 & S3 & ZPT \\
\hline H1 & $0,77 \mathrm{a}$ & $0,15 \mathrm{c}$ & $0,40 \mathrm{abc}$ & $0,44 \mathrm{a}$ \\
$\mathrm{H} 2$ & $0,67 \mathrm{ab}$ & $0,40 \mathrm{abc}$ & $0,25 \mathrm{bc}$ & $0,44 \mathrm{a}$ \\
$\mathrm{H} 3$ & $0,30 \mathrm{bc}$ & $0,10 \mathrm{c}$ & $0,63 \mathrm{ab}$ & $0,34 \mathrm{a}$ \\
\hline Pengaruh Umum Sayatan & $0,58 \mathrm{a}$ & $0,22 \mathrm{a}$ & $0,43 \mathrm{a}$ &
\end{tabular}


Ket: $\quad \mathrm{H} 1=\mathrm{ZPT}$ air kelapa, $\mathrm{H} 2=\mathrm{ZPT}$ ekstrak bawang merah, $\mathrm{H} 3=\mathrm{ZPT}$ ekstrak tauge, $\mathrm{S} 1=$ tipe sambung pucuk celah $\mathrm{S} 2=$ tipe sambung pucuk canggap $\mathrm{S} 3=$ tipe sambung pucuksisip.

Berdasarkan Tabel 4, menunjukkan kombinasi jenis zat pengatur tumbuh dan tipe sayatan. Akan tetapi, pada faktor tunggal tipe sayatan nilai tertinggi terdapat pada perlakuan S1 (tipe sayatan celah). Sedangkan faktor tunggal jenis zat pengatur tumbuh terdapat pada H1 dan H2 (zpt air kelapa dan ekstrak bawang merah).

Tabel. 5 Diameter Batang Bawah (cm)

\begin{tabular}{lllll}
\hline Pengaruh Tunggal & \multicolumn{3}{c}{ Pengaruh TunggalSayatan } & Pengaruh Umum \\
\cline { 2 - 4 } ZPT & $\mathrm{S} 1$ & $\mathrm{~S} 2$ & $\mathrm{~S} 3$ & ZPT \\
\hline $\mathrm{H} 1$ & $0,97 \mathrm{a}$ & $0,17 \mathrm{c}$ & $0,48 \mathrm{abc}$ & $0,54 \mathrm{a}$ \\
$\mathrm{H} 2$ & $0,83 \mathrm{ab}$ & $0,45 \mathrm{abc}$ & $0,32 \mathrm{bc}$ & $0.53 \mathrm{a}$ \\
$\mathrm{H} 3$ & $0,37 \mathrm{bc}$ & $0,15 \mathrm{c}$ & $0,82 \mathrm{ab}$ & $0,44 \mathrm{a}$ \\
\hline $\begin{array}{l}\text { Pengaruh Umum } \\
\text { Sayatan }\end{array}$ & $0,72 \mathrm{a}$ & $0,26 \mathrm{a}$ & $0,54 \mathrm{a}$ & \\
\hline
\end{tabular}

Ket: $\quad$ H1= ZPT air kelapa, H2= ZPT ekstrak bawang merah, H3= ZPT ekstrak tauge, S1= tipe sambung pucuk celah $\mathrm{S} 2=$ tipe sambung pucuk canggap $\mathrm{S} 3=$ tipe sambung pucuksisip.

Berdasarkan Tabel 5, menunjukkan kombinasi jenis zat pengatur tumbuh dan tipe sayatan. Akan tetapi, pada faktor tunggal tipe sayatan nilai tertinggi terdapat pada perlakuan S1 (tipe sayatan celah). Sedangkan faktor tunggal jenis zat pengatur tumbuh terdapat pada H1 dan H3 (zpt air kelapa dan ekstrak tauge).

\section{PEMBAHASAN}

Berdasarkan uji lanjutan DMRT taraf 5\% perlakuan kombinasi zat pengatur tumbuh alami dan tipe sayatan menunjukkan berbeda nyata pada parameter keberhasilan sambung hidup, jumlah daun, pertambahan panjang entres, diameter batang atas dan diameter batang menunjukkan berbeda nyata.

Dari hasil penelitian ini pada parameter keberhasilan sambung hidup menunjukkan terdapat interaksi kombinasi antara perlakuan tipe sayatan dan zat pengatur tumbuh. Kombinasi terbaik pada parameter keberhasilan sambung hidup yaitu H2S1 (ZPT ekstrak bawang merah dan sambung celah). Menurut Muswita (2011) menambahkan, fitohormon yang dikandung bawang merah adalah auksin. Auksin berfungsi untuk mempengaruhi pertambahan panjang batang, pembelahan sel, pertumbuhan diferensiasi, percabangan biji, perkembangan kuncup, pemanjangan batang, pertumbuhan daun, dan mempengaruhi pertumbuhan percabangan.

Menurut lasimin et al.(2002) Menyatakan pada parameter keberhasilan sambung hidup, umur peceh tunas dan pembentukan daun menunjukkan hasil tertinggi dibandingkan sambung pucuk lainnya. Hartmann et al.(1978) Menambahkan teknik sambung celah, bidang sambungan terutama pada batang bawah yang setelah dibelah langsung diselipkan batang atas sehingga peluang untuk terjadinya kekeringan kambium kecil sekali. Keadaan ini akan mendorong dengan cepat terjadinya proses pembelahan sel. Pada tanaman jeruk, awal pembelahan sel dimulai 24 jam setelah sambung.

Proses pertautan batang atas dan batang bawah akan terjadi melalui empat tahap, yaitu pembesaran dan pembelahan sel kambium baru yang menghubungkan kambium batang atas dan batang bawah, pembentukan jaringan vaskuler yang mengalirkan nutrisi dan air dari batang bawah ke batang atas. sel kambium baru dan vaskuler baru ke dalam membentuk xilem dan keluar membentuk floem (Ferdinandus 2011).

Dari hasil penelitian ini pada parameter pertambahan panjang entres, jumlah daun, diameter batang atas dan diameter batang bawah menunjukkan nilai kombinasi tertinggi, yaitu H1S1 (ZPT air kelapa dan sambung celah). Rosmawati, Iwan (2018), menyatakan hasil pengamatan terhadap panjang tunas sambung pucuk,model sambung celah (S1) menunjukkan pengaruh nyata pertambahan panjang tunas bibit. Susilo, Sobadi (2008), menambahkan kompatibilitas penyambungan merupakan interaksi yang terjadi antara batang bawah dengan batang atas. Didalam pertautan batang bawah dan batang atas dalam penyatuan kalus terdapat peran hormon untuk mempercepat pertautan. Dari penelitian ini, terdapat interaksi sambung celah dengan hormon air kelapa. Pada Air kelapa merupakan salah satu produk tanaman yang dapat dimanfaatkan untuk meningkatkan pertumbuhan tanaman. Air kelapa diduga mengandung hormon pertumbuhan, yakni sitokinin dan auksin. 
Hal ini dikarenakan adanya hormon auksin dan sitokinin mampu mempengaruhi proses pembelahan sel dan pemanjangan sel pada proses penyambungan. Hal ini sejalan dengan pendapat Lakitan (2001) bahwa pertumbuhan panjang tunas dipengaruhi oleh hormon auksin dan sitokinin. Sitokinin akan merangsang pembelahan sel melalui peningkatan laju sintesis protein, sedangkan auksin akan memacu pemanjangan sel-sel yang menyebabkan pemanjangan batang pendapat Pina dan Errea (2005) menyatakan tahapan terjadinya kompatibilitas penyambungan diawali dengan terbentuknya sel-sel parenkim yang akan menghubungkan jaringan batang atas dengan jaringan batang bawah kemudian kalus terdeferensiasi menjadi jaringan pengangkut (phloem dan xylem). Kompatibilitas penyambungan terjadi apabila jaringan pengangkut tersebut dapat berfungi secara baik untuk menghubungkan jaringan bawah dengan batangatas.

Menurut Hartman (1997) faktor lain yang mempengaruhi diameter batang atas, diameter batang bawah, tinggi tanaman dan jumlah daun adalah daya gabung (kompatibilitas) antara batang atas dan batang bawah. Kompatibilitas mempengaruhi kelangsungan hidup tanaman hasil sambungan dan berlanjut pada bertambahnya panjang entres dan pertambahan diameter batang bawah. Pada penyambungan yang kompatibel diduga terjadi lignifikasi dinding sel yang dapat menyatukan sel-sel yang berdekatan di luar daerah penyatuan sambungan. Sebaliknya dinding sel daerah penyatuan sambungan pada gabungan yang inkompatibel tidak menghasilkan lignin dan hanya dihubungkan oleh serat selulosa (Hartman 1997). Cicilia juga menyatakan (2017) bahwa gagalnya penyatuan antara batang atas dan batang bawah (inkompatibilitas) dapat disebabkan oleh respon fisiologi antara kedua bagian yang disambungkan, transmisi virus atau fitoplasma dan kelainan anatomi jaringan pembuluh pada jembatan kalus.

Sesuai dengan pernyataan dari Tirtawinata (2003) dan Tambing (2004), bahwa faktorfaktor yang mempengaruhi keberhasilan penyambungan tanaman adalah faktor tanaman, mencakup keserasian antara batang bawah dan batang atas, kehalusan sayatan untuk memastikan sentuhan kambium, dan kesamaan ukuran batang bawah dan batang atas. Selain itu, terdapat faktor lainnya yaitu faktor lingkungan dan pelaksanaan. Pada faktor lingkungan diantaranya, waktu penyambungan sebaiknya dilakukan pada musim kemarau karena pertumbuhan batang dalam keadaan aktif dan entres umumnya telah cukup masak. Suhu optimal untuk penyambungan adalah $25-30 \mathrm{oC}$ dengan kelembaban udara yang tinggi. Sedangkan faktor pelaksanaan, mencakup keterampilan dan keahlian melaksanaan penyambungan serta ketajaman alat yang digunakan.

Menurut Mathius et al. (2007) Faktor lingkungan yang mempengaruhi pertumbuhan tanaman pada saat melaksanakan penelitian adalah curah hujan di lapangan cukup tinggi sehingga bisa membuat sambungan basah yang mempengaruhi penyatuan jaringan pada titik sambung. Menurut Persaulian et al. (2012) curah hujan yang tinggi menyebabkan basahnya sambungan, kondisi ini terutama pada saat hujan turun dengan waktu yang cukup lama. Ketersediaan air sangat mempengaruhi pertumbuhan, terutama perkembangan sel, namun air juga dapat memberikan pegaruh yang negatif bagi tanaman, khususnya pada saat sambungan belum menyatu sempurna, adanya titik-titik air dapat menyebabkan kebusukan pada sayatan.

\section{KESIMPULAN}

Adapun kesimpulan pada penelitian ini adalah sebagai berikut:

Hasil penelitian ini pada semua parameter yaitu keberhasilan sambung hidup, jumlah daun, pertambahan panjang entres, diameter batang atas dan diameter batang bawah terdapat pengaruh kombinasi perlakuan zat pengatur tumbuh alami dan tipe sayatan. Pada parameter keberhasilan sambung hidup yang menunjukkan nilai tertinggi yaitu H2S1 (ZPT ekstrak bawang merah dan sambung celah). Sedangkan pada parameter pertambahan panjang entres, jumlah daun,diameter batang atas dan diameter batang bawah menunjukkan nilai tertinggi yaitu H1S1 (ZPT air kelapa dan sambung celah).

\section{DAFTAR PUSTAKA}

Arif M. 2016. Uji beberapa zat pengatur tumbuh alami terhadap pertumbuhan bibit karet (Hevea brasiliensis Muell Arg) stum mata tidur. Jurnal. Universitas Riau.

Amaliah, Yuli A. 2006. Penggunaan konsentrasi ekstak kecambah kacang hijau pada media Vacin dan Went (VW) tehadap pertumbuhan kecambah anggrek bulan. Buletin Penelitian. Yogyakarta. 
Badan Pusat Statistik. 2016. Tabel dinamis: produksi tanaman buah-buahan, durian (Ton).

Ferdinandus, R. 2011. Okulasi Tanaman Durian "Durio zibethinus Murr" dengan Asal Tunas Batang dan Cara Pemotongan Batang Bawah. Skripsi. Jurusan Agronomi, Fakultas Pertanian, Universitas Sebelas Maret. Surakarta.

Somsri S. 2008. Durian: south east asia's king of fruits. Chronic Horticulture 48(4): 19-22.

Sumarsono L, Sjaefuddin A, Dimyati D, Abdurahman, Sudiyanti. 2012. Teknik sambung pucuk dengan entres tidak bercabang dan bercabang pada pembibitan tanaman manggis. Buletin Teknik Pertanian 7 (1): 37-40.

Rosmawati, Iwan S. 2018. Kombinasi Waktu Defoliasi Entres Dan Model Sambung Pucuk Terhadap Pertumbuhan Bibit Cacao (Theobroma Cacao, L). Universitas samudra. Jurnal Ilmiah Pertanian.

Hartmann H T, D E Kester, F T Davies Jr, Geneve. 1997. Plant Propagation Principles and Practices. 6th ed. Pentice-Hall, inc. Engle Wood. New York

Lasimin S 2002. Teknik Okulasi Bibit Durian pada stadia entres dan model mata tempel yang berbeda. Jurnal Teknik Pertanian.

Yusnida B. 2006. Pengaruh Pemberian Giberelin (GA3) dan Air Kelapa Terhadap Perkecambahan Bahan Biji Anggrek bulan (Phalaenopsis amabilis) 